\title{
PENGARUH KEKAKUAN BULU SIKAT GIGI TERHADAP \\ PENURUNAN JUMLAH INDEKS PLAK PADA ANAK SEKOLAH DASAR KECAMATAN IWOIMENDA KABUPATEN KOLAKA
}

\author{
R. Ardian Priyambodo; Musdalifa
}

\begin{abstract}
ABSTRAK
Pentingnya menjaga kesehatan gigi dan mulut belum disadari oleh seorang anak maka orang tua memiliki tanggung jawab dalam mengontrol kesehatan gigi dan mulut anak utamanya dalam hal menyikat gigi. Pemilihan jenis bulu sikat gigi merupakan hal yang sangat menentukan efisiensi pembersihan plak pada rongga mulut sehingga orang tua perlu memilih jenis bulu sikat gigi yang tepat untuk anak. Sikat gigi beredar di pasaran dengan berbagai derajat kekakuan dimulai dari lembut (soft), sedang (medium), tetapi seorang anak hanya dianjurkan menggunakan bulu sikat gigi lembut (soft) dan sedang (medium). Tujuan penelitian ini adalah untuk mengetahui perbedaan pengaruh kekakuan bulu sikat gigi lembut (soft) dan sedang (medium) terhadap penurunan jumlah plak pada anak. Metode penelitian yang digunakan adalah metode eksperimental semu dengan pendekatan pre-test dan post-test antara bulu sikat gigi lembut (soft) dan bulu sikat gigi sedang (medium). Berdasarkan hasil uji Independent T-test untuk mengetahui apakah terdapat perbedaan efektifitas dalam menurunkan jumlah plak, untuk sikat gigi sedang (medium) memiliki rata-rata nilai penurunan jumlah plak sebesar 1.157, sedangkan untuk sikat gigi lembut (soft) memiliki rata-rata nilai penurunan jumlah plak sebesar 2.300. Derajat kekakuan bulu sikat gigi sedang (medium) memiliki efektifitas lebih tinggi dalam menurunkan jumlah plak dibandingkan sikat gigi lembut (soft).
\end{abstract}

Kata kunci: sikat gigi berbulu halus (soft), sikat gigi berbulu sedang (medium), indeks plak

\section{PENDAHULUAN}

Kesehatan gigi merupakan bagian integral dari kesehatan secara keseluruhan yang dapat mempengaruhi kualitas hidup. Gigi dan mulut dikatakan sehat apabila memiliki oral hygiene yang baik, yaitu kondisi gigi dan mulut yang bebas dari debris, plak, serta kalkulus. Seorang anak masih belum menyadari arti penting menjaga kesehatan gigi dan mulut dengan cara selalu menjaga kebersihan gigi dan mulutnya, sehingga menjaga kebersihan gigi dan mulut anak harus mendapat perhatian orang tua. Apabila kesehatan gigi dan mulut buruk, misalnya terdapat karies dan gingivitis akan menyebabkan fungsi pengunyahan menjadi tidak optimal, sehingga menyebabkan penurunan berat badan anak (Pratiwi, 2017).

Selain peran orang tua dalam membimbing, memberikan pengertian dan mengingatkan anak untuk menjaga kesehatan gigi dan mulut, perlu dilakukan penyuluhan tentang kesehatan gigi dan mulut oleh tenaga kesehatan. Penyuluhan kesehatan gigi dan mulut merupakan salah satu upaya untuk mencegah masalah kesehatan gigi dan mulut, dengan tercapainya tingkat kesehatan gigi yang lebih baik di masa mendatang. Kebersihan gigi yang kurang baik dapat menyebabkan terjadinya akumulasi plak. Salah satu cara menghilangkan plak yaitu dengan menyikat gigi. Plak gigi adalah suatu lapisan lunak yang tidak berwarna terdiri dari kumpulan mikroorganisme yang berkembang biak diatas suatu matriks yang terbentuk dan melekat erat pada permukaan gigi, tumpatan maupun kalkulus yang tidak dibersihkan (Houwink, 1993).

Menjaga kesehatan gigi dapat dilakukan dengan menyikat gigi, tujuannya adalah menghilangkan plak pada permukaan gigi sehingga kebersihan gigi dan mulut tetap baik (Wuriyanti,2009). Penelitian RISKERDAS 2007 tentang pengaruh kebiasaan menyikat gigi terhadap prevalensi karies menyimpulkan bahwa responden yang memiliki kebiasaan menyikat gigi hanya setelah sarapan berisiko karies 1,4 kali dibandingkan dengan yang memiliki kebiasaan menyikat gigi setelah sarapan dan sesudah sarapan dan sebelum tidur malam (Jovina, 2010).

Sikat gigi dalam menjalankan fungsinya sebagai alat yang digunakan untuk membersihkan 
gigi memiliki beberapa bagian yang saling mendukung satu dengan yang lainnya, namun bagian terpenting dari sikat gigi adalah bulu sikat gigi karena bersentuhan langsung dengan permukaan gigi. Derajat kekakuan bulu sikat gigi merupakan faktor yang berhubungan dengan efek pembersihan dan trauma jaringan akibat menyikat gigi, derajat kekakuan bulu sikat gigi dipengaruhi oleh ketebalan dan panjang bulu sikat gigi, semakin tebal dan pendek bulu sikat gigi maka derajat kekakuan bulu sikat gigi akan semakin meningkat, begitu juga sebaliknya (Hamsar, 2005). Saat ini sikat gigi yang beredar di pasaran terdiri dari berbagai macam variasi dalam hal bentuk, ukuran, dan derajat kekakuan bulu sikat gigi. Pada umumnya bulu sikat gigi terbagi dalam tiga jenis berdasarkan derajat kekakuan bulu sikat, yaitu lembut (soft), sedang (medium), dan keras (hard), efektifitas dalam menghilangkan plak dari masing-masing derajat kekakuan bulu sikat gigi juga berbeda. Pada kelompok yang menggunakan bulu sikat gigi keras (hard) terjadi peningkatan prevalensi resesi gingiva sejalan dengan ditingkatkannya frekuensi menyikat gigi, sedangkan pada kelompok yang menggunakan bulu sikat gigi lembut (soft) dan sedang (medium) tidak terjadi peningkatan prevalensi resesi gingiva walaupun frekuensi menyikat gigi ditingkatkan (Jovina, 2010). Hal tersebut yang mendasari bahwa pada umumnya anak-anak dianjurkan menggunakan sikat gigi berbulu lembut (soft) dan sedang (medium) dan tidak menggunakan bulu sikat gigi keras (hard) (Hamsar, 2005).

Budha (2014), menyatakan bahwa hasil uji Independent T-test untuk mengetahui apakah terdapat perbedaan efektivitas dalam menurunkan jumlah plak, untuk sikat gigi sedang (medium) memiiliki rata-rata nilai penurunan jumlah plak sebesar 12,43, sedangkan untuk sikat gigi lembut (soft) memiliki rata-rata nilai penurunan jumlah plak sebesar 5,27. Derajat kekakuan bulu sikat gigi sedang (medium) memiliki efektifitas lebih tinggi dalam menurunkan jumlah Plak dibandingkan sikat gigi lembut (soft).

\section{METODE PENELITIAN}

Jenis penelitian yang digunakan adalah penelitian eksperimental semu dengan pendekatan pre test dan post test dengan grup kontrol antara bulu sikat gigi lembut (sotf) dengan bulu sikat gigi sedang (medium). Populasi adalah selutuh murid SDN 1 Iwoimendaa Kabupaten Kolaka, sedangkan sampel diambil dari popusai sebayak 30 orang siswa kelas V. Penelitian ini dimulai pada bulan Mei-Juni 2018. Instrumen penelitian yang digunakan untuk mengetahui tingkat kebersihan mulut adalah indeks PHP-M. Metode ini sering digunakan untuk pemeriksaan kebersihan gigi dan mulut pada masa geligi campuran. Indeks PHP-M digunakan untuk mengukur plak secara obyektif. Pemeriksaan PHP-M menggunakan gigi yang sudah ditentukan dan menggunakan disclosing agent. (Nurjannah, 2012). Gigi yang diperiksa pada metode PHP-M ini adalah: (1) gigi paling posterior yang tumbuh di kwadran kanan atas, (2) gigi kaninus atas kanan sulung atau permanen, bila gigi ini tidak ada dapat digunakan gigi anterior lainnya (3) Gigi molar satu atas kiri sulung atau premolar satu atas kiri, (4) Gigi paling posterior yang tumbuh di kwadran kiri bawah, (5) gigi kaninus kiri bawah sulung atau permanen, bila gigi ini tidak ada dapat dipakai gigi anterior lainnya, (6) gigi molar satu kanan bawah sulung atau premolar satu kanan bawah.

Cara penilaian skor plak pada PHP-M adalah, pertama-tama pada permukaan bukal dan lingual gigi dibagi menjadi beberapa area untuk memudahkan dalam menentukan skor, dibuat dua garis imajiner pada gigi dari oklusal atau insisal menuju gingival, garis imajiner ini akan membagi gigi menjadi tiga bagian yang sama dari mesial ke distal. Tahap selanjutnya membagi area sepertiga tengah menjadi tiga area dengan cara menarik du garis imajiner dari mesial menuju distal sehingga akan membagi area sepertiga tengah tersebut menjadi tiga bagian yang sama dari oklusal ke gingival. Jadi akan didapat lima area pada satu permukaan gigi saja (bukal atau lingual), yaitu: sepertiga gingival dari area tengah, sepertiga 
tengah dari area tengah,sepertiga insisal atau oklusal dari area tengah, distal dan mesial. Apabila terlihat ada plak di salah satu area, maka diberi skor 1, jikatidak ada plak diberi skor 0 . Hasil penilaian plak yaitu dengan menjumlahkan setiap skor plak pada setiap permukaan gigi, sehingga skor plak untuk setiap gigi dapat berkisar antara 010. Skor plak untuk semua gigi dapat berkisar antara 0-60 (Nurjannah, 2012).

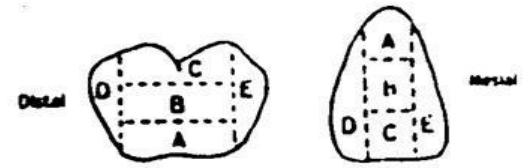

Analisis data menggunakan uji paired T-test dan uji independent T-test dengan program SPSS, yaitu: Uji paired T-test untuk mengetahui perbedaan indeks plak sebelum dan sesudah menyikat gigi baik pada sikat gigi lembut (soft) maupun pada sikat gigi sedang (medium). Uji independent T-test untuk mengetahui perbedaan penurunan indeks plak antara penggunaan bulu sikat lembut (soft) dan sedang (medium). Uji independent T-tes untuk mengetahui perbedaan penurunan indeks plak antara penggunaan bulu sikat lembut (soft) dan sedang (medium).

\section{HASIL DAN PEMBAHASAN}

\section{Karakteristik Responden}

Responden pada penelitian ini adalah murid kelas 5 SD Negeri 1 Iwoimendaa yang berjumlah 30 orang, dengan karakteristik responden sebagai berikut:

Tabel 1. Karakteristik Responden

\begin{tabular}{|c|c|c|}
\hline Jenis Kelamin & Frekuensi & Persen \\
\hline Laki-laki & 21 & 70.0 \\
\hline Perempuan & 9 & 30.0 \\
\hline Total & 30 & 100.0 \\
\hline
\end{tabular}

Dari tabel $d$ atas dapat diketahui responden berjenis kelamin laki-laki berjumlah 21 orang dan responden berjenis kelamin perempuan berjumlah 9 orang, umur responden berkisar antara 10 sampai 11 tahun.

\section{Analisis Antar Variabel}

Untuk menentukan apakah data yang terkumpul sudah terdistribusi secara normal maka dilakukan uji normalitas dengan menggunakan uji Kolmogorov- Smirnov. Hasil uji normalitas menunjukan pada kedua tingkat kekakuan bulu sikat nilai p (signifikan) lebih dari 0,05 ( $p>0,05)$, sehingga dapat dikatakan data sudah terdistribusi secara normal. Data yang dinyatakan terdistribusi secara normal dapat dilakukan uji selanjutnya yaitu uji Paired T-test.

Untuk melihat adanya perbedaan antara sebelum dan sesudah pemakaian sikat gigi lembut (soft) digunakan uji Paired T-test, hasil dari uji ini akan dipakai untuk menganalisis data pada uji Independent T-test nantinya yang berfungsi untuk menunjukkan ada atau tidaknya perbedaan efektifitas dalam menurunkan plak dan untuk menentukan jenis bulu sikat gigi mana yang memiliki efektifitas lebih tinggi dibandingkan yang lainnya. Hasil dapat dilihat pada tabel 2 di bawah ini : 
Tabel 2 Perbedaan Penurunan Jumlah Plak Sebelum dan Sesudah Penggunaan Sikat Gigi Lembut (Soft).

\begin{tabular}{|l|l|c|c|}
\hline \multicolumn{2}{|c|}{ Menyikat gigi } & Mean & N \\
\hline \multirow{2}{*}{$\begin{array}{l}\text { Sikat Gigi Lembut } \\
\text { (Soft) }\end{array}$} & Sebelum & 3.460 & 30 \\
\cline { 2 - 4 } & Sesudah & 2.420 & 30 \\
\hline
\end{tabular}

Dari tabel di atas maka dapat diketahui hasil

sebelum dan sesudah perlakuan dengan menggunakan sikat gigi lembut (soft) terdapat perbedaan nilai mean jumlah plak sebelum menyikat gigi 3.460 dan setelah menyikat gigi
2.420 dengan selisih mean adalah 1. Untuk melihat adanya perbedaan penurunan jumlah plak antara sebelum dan sesudah pemakaian sikat gigi sedang (medium) dapat dilihat pada tabel 3.di bawah ini ;

Tabel 3. Hasil Uji Perbedaan Penurunan Jumlah Plak Sebelum dan Sesudah

Penggunaan Sikat Gigi Sedang (Medium)

\begin{tabular}{|c|l|c|c|}
\hline \multicolumn{2}{|c|}{ Menyikat gigi } & Mean & N \\
\hline $\begin{array}{c}\text { Sikat Gigi Sedang } \\
\text { (Medium) }\end{array}$ & Sebelum & 3.357 & 30 \\
\cline { 2 - 3 } & Sesudah & 1.157 & 30 \\
\hline
\end{tabular}

Mempelajari tabel di atas maka dapat diketahui hasil sebelum dan sesudah perlakuan dengan menggunakan sikat gigi sedang (medium) dapat perbedaan nilai mean penurunan jumlah plak sebelum menyikat gigi 3,357 dan setelah menyikat gigi 1,157 dengan selisih mean adalah
2,2. Untuk dapat mengetahui adanya perbedaan pengaruh efektifitas dalam menurunkan jumlah plak pada anak antara penggunaan sikat gigi lembut (soft) dan sikat gigi sedang (medium) menggunakan Independent T-test dapat dilihat pada tabel 4 di bawah ini:

Tabel 4. Hasil Uji Perbedaan Penurunan Jumlah Plak Antara Sikat Gigi Soft dan Medium

\begin{tabular}{|c|c|c|c|}
\hline \multirow{3}{*}{ Nilai } & Jenis & $\mathrm{N}$ & Mean \\
\cline { 2 - 4 } & Soft & 30 & 2.300 \\
\cline { 2 - 4 } & Medium & 30 & 1.157 \\
\hline
\end{tabular}

Berdasarkan hasil Independent T-test yang ditampilkan pada tabel 4 dapat dilihat adanya perbedaan pengaruh efektifitas dalam menurunkan plak antara penggunaan sikat gigi lembut (soft) dan sikat gigi sedang (medium) yang ditunjukan dari nilai sig. Kurang dari 0,05 sedangkan untuk menentukan sikat gigi yang memiliki efektifitas lebih tinggi dibandingkan yang lainnya dalam menurunkan jumlah plak pada anak ditunjukkan dari hasil pada kolom mean. Hasil pada kolom mean tersebut menunjukkan perbandingan rata-rata selisih penurunan jumlah plak sebelum dan sesudah menyikat gigi pada masing-masing tingkat kekakuan bulu sikat gigi, pada tabel tersebut terlihat hasil mean dari sikat gigi sedang (medium) lebih tinggi dibandingkan sikat gigi lembut (soft) hal tersebut menunjukkan bahwa sikat gigi sedang (medium) memiliki efektifitas yang lebih tinggi dalam menurunkan plak dibandingkan sikat gigi lembut (soft).

Bagian dari sikat gigi yang berperan paling penting dalam fungsinya sebagai pembersih gigi dan rongga mulut adalah bulu sikat gigi. Derajat kekakuan bulu sikat gigi dibuat bervariasi fungsinya untuk menyesuaikan dengan keadaan atau kebutuhan yang berbeda-beda dari rongga mulut setiap orang. Menurut Hamsar (2005) derajat kekakuan bulu sikat gigi ditentukan 
oleh diameter dan panjang bulu sikat, semakin tebal dan pendek bulu sikat maka derajat kekakuan bulu sikat akan semakin meningkat, sebaliknya semakin tipis dan panjang bulu sikat maka derajat kekakuan bulu sikat akan semakin menurun. Ditinjau dari ketebalan bulu sikat gigi, Carranza (1990) menyatakan bahwa bulu sikat gigi lembut (soft) diameternya sekitar 0,2 mm sedangkan pada bulu sikat gigi sedang (medium) diameternya sekitar $0,3 \mathrm{~mm}$, setiap derajat kekakuan bulu sikat gigi hanya berbeda beberapa milimeter.

Bulu sikat gigi lembut (soft) memiliki fleksibilitas yang tinggi dan sangat tipis sehingga dapat menjangkau sela-sela antar gigi (daerah interdental), sulkus gingiva serta daerah lekukan pada gigi. Kelebihan lain dari bulu sikat gigi lembut (soft) tidak menimbulkan resesi gingiva (peradangan pada gusi), tetapi terdapat kekurangan pada bulu sikat gigi lembut (soft) yaitu bulu sikat gigi ini kurang maksimal dalam mengikis timbunan plak yang tebal dan keras pada permukaan gigi (Srigupta, 2004). Sebaliknya, semakin tinggi derajat kekakuan bulu sikat gigi maka akan lebih efektif dalam mengangkat plak pada permukaan gigi, tetapi kekurangannya dapat mengakibatkan peradangan pada gingiva (Carranza,1990).

Bulu sikat gigi sedang (medium) lebih baik membersihkan plak daripada sikat gigi yang lembut (soft). Bulu sikat gigi lembut lebih baik dan fleksibel membersihkan daerah sulkus gingiva dan interdental, tetapi tidak dapat membersihkan plak yang tebal dan keras (Dewi, 2003).

Penelitian ini menggunakan teknik menyikat gigi Roll pada perlakuan sampel, teknik ini sering dianjurkan oleh dokter gigi karena sederhana tetapi efektif dan efisien dalam membersihkan gigi dan mulut. Teknik ini juga dapat digunakan di seluruh bagian mulut sehingga memudahkan anak-anak untuk melakukannya. Cara kerja dari teknik ini adalah dengan cara menempatkan bulu-bulu sikat gigi pada tepi gusi dengan ujung-ujung bulu sikat gigi mengarah ke apeks dan sisi bulu sikat gigi digerakkan perlahanlahan melalui permukaan gigi sehingga bagian belakang dari kepala sikat gigi bergerak dengan lengkungan. Pada waktu bulu-bulu sikat gigi melalui mahkota klinis, kedudukannya hampir tegak lurus permukaan email, gerakan ini diulang 8-12 kali pada setiap daerah dengan sistematis sehingga tidak ada yang terlewat. Cara ini akan menghasilkan pemijatan gusi, dapat membersihkan sisa makanan dari daerah interproksimal karena gerakannya yang didominasi oleh gerakan vertikal, dan sangat jarang menyebabkan abrasi pada email (Notoatmodjo, 2012).

Analisis data dari penelitian yang dilakukan pada tanggal 24 dan 25 Juni 2018 pada murid kelas 5 SD Negeri 1 Iwoimendaa ini menunjukkan bahwa terdapat perbedaan yang signifikan dalam efektifitas menurunkan jumlah plak pada gigi anak antara penggunaan sikat gigi lembut (soft) dengan sikat gigi sedang (medium), hal tersebut dapat dilihat dari hasil pengolahan data menggunakan uji independent T-test dimana nilai signifikansinya kurang dari 0,05. Hasil uji analisis tersebut memperlihatkan bahwa terdapat nilai penurunan jumlah plak yang lebih besar pada sikat gigi yang berbulu sedang (medium) yaitu sebesar 1.157 dibandingkan dengan sikat gigi berbulu halus (soft) yaitu sebesar 2,300, dengan selisih perbedaan penurunan plak diantara kedua jenis bulu sikat tersebut adalah 1.143. Jadi dapat dikatakan bulu sikat sedang (medium) memiliki efektifitas dalam menurunkan plak pada anak lebih baik dibandingkan dengan bulu sikat lembut (soft) (Hamsar, 2005). Penelitian yang dilakukan oleh Hamsar (2005) menyimpulkan hasil yang sama, yaitu penurunan indeks plak pada sikat gigi berbulu sedang (medium) rata-rata sebesar 1,32 sedangkan pada sikat gigi berbulu lembut (soft) sebesar 1,11. Jadi terdapat selisih perbedaan efektifitas 0,21 diantara kedua derajat kekakuan bulu sikat, terlihat penurunan sindeks plak pada bulu sikat gigi sedang (medium) lebih tinggi dibandingkan bulu sikat lembut (soft). Begitu juga 
terkait dengan pendapat Dewi (2003) yang menyatakan bahwa tingkat kekakuan bulu sikat gigi jika diukur efektifitasnya dalam menurunkan jumlah plak dari yang paling tinggi sampai yang paling rendah adalah dimulai dari sikat gigi berbulu sedang (medium), lalu yang paling terakhir adalah bulu sikat gigi lembut (soft). Bulu sikat gigi sedang (medium) memiliki efktifitas lebih tinggi dalam menurunkan jumlah plak dibandingkan dengan bulu sikat gigi lembut (soft) dengan tidak mengiritasi gingiva dikarenakan bulu sikat gigi sedang (medium) memiliki diameter bulu sikat 0,012 inchi $(0,3 \mathrm{~mm})$ sehingga tingkat elastisitasnya cukup untuk mengangkat plak yang tebal dan keras tanpa merusak jaringan periodontal gigisedangkan bulu sikat gigi lembut (soft) tingkat elastisitasnya terlalu tinggi (diameternya berkisar pada 0,07 inchi atau 0,2 $\mathrm{mm}$ ), sehingga tidak dapat mengangkat plak yang lapisannya sudah tebal dan keras, akibatnya tidak semua plak pada permukaan gigi dapat terangkat (Besford, 1996).

\section{SIMPULAN DAN SARAN Simpulan}

Bulu sikat gigi lembut (soft) dapat menurunkan jumlah indeks plak, demikian juga bulu sikat gigi sedang (medium) dapat menurunkan jumlah indeks plak., namun bulu sikat gigi sedang (medium) lebih efektif dalam menurunkan jumlah indeks plak

\section{Saran}

$$
\text { Dari hasil penelitian lebih }
$$

direkomendasikan untuk menggunakan sikat gigi sedang (medium) karena bulu sikat gigi sedang lebih efektif dalam menurunkan jumlah indeks plak.

\section{DAFTAR PUSTAKA}

1. Besford, J., 1996. Mengenal Gigi Anda: Petunjuk Orang Tua. s.l.:s.n.

2. Budha, D. M. A. S., 2014. Pengaruh Kekakuan Bulu Sikat Gigi Terhadap Penurunan Jumlah Plak Pada Anak.. FKG Universitas Mahasaraswati.
3. Carranza, F. A., 1990. Periodontal Disease: Classification of Periodontal Disease, dalam Glickman's Clinical Periodontology. 2nd ed. Jakarta: s.n.

4. Haryanti D.D, Adhani R, Aspriyanto D, Dewi I.K., 2014. Efektifitas Menyikat Gigi MetodeHorizontal, Vertikal, dan Roll Terhadap Penurunan Plak Pada Anak Usia 9-11 Tahun. Dentino Jurnal Kedokteran Gigi, Volume 2, p. 150.

5. Houwink.B, 1993. Ilmu Kedokteran Gigi Pencegahan. Yogyakarta: Gajah Mada University Press.

6. Houwink, B., 1984. IImu Kedokteran Gigi Pencegahan. Jakarta: Hipokrates.

7. Ilyas M, Putri IN., 2012. Efek Penyuluhan Metode Demonstrasi Menyikat Gigi Terhadap Penurunan Indeks Plak Gigi pada Murid Sekolah Dasar.. Dentofasial Jurnal Kedokteran Gigi, 11(2), pp. 91-5.

8. Jovina, T. A., 2010. Pengaruh Kebiasaan Menyikat Gigi Terhadap Status Kesehatan In: Kesehatan Mulut. 1st ed. Jakarta: Prestasi Pustaka, pp. 227-237.

9. Kidd, E. A. M. dan Bechal, S. J. , 2012. Dasar-Dasar Karies: Penyakit Dan Penanggulangannya. 3rd ed. Jakarta: EGC.

10. Kidd, E. A. M. dan Bechal, S. J., 2012. Dasar-Dasar Karies: Penyakit Dan Penanggulangannya. 3rd ed. Jakarta: Buku Kedokteran EGC.

11. Kidd.E.A.M, Joyston S., 2008. Dasar-Dasar Karies Penyakit dan Penanggulangannya. Jakarta: EGC.

12. Kompas, 2007. Gigi Sehat Merawat Gigi Sehari-hari. [Online] Available at: http://unmas library.ac.id/wpcontent/uploads/2014/06/SKR IPSI6.pdf [Accessed 2 Oktober 2016].

13. Notoatmodjo, S. S. K. M., 2012. Promosi Kesehatan Dan Perilaku Kesehatan. s.I.:s.n.

14. Putri, M. H., Herijulianti, E., dan Nurjannah, N., 2012. IImu Pencegahan Penyakit Jaringan Keras dan Jaringan Pendukung Gigi. 2nd ed. Jakart: EGC.

15. Roeslan, B. O., 2002. Imunologi Oral: Kelainan di Dalam Rongga Mulut. 1st ed. Jakarta: Balai Penerbit Fakultas Kedokteran Universitas Indonesia.

16. Russekk, Aderson G., n.d. Soft vs Hard Bristle Toothbrush. [Online]

Available at: http//www.beamingsmies.com/blog/post/softvs-hard-bristletoothbrush.html [Accessed 12 November 2016]

17. Sari, E. K., Ulfiana, E., dan Dian, P., 2002. Pengaruh Pendidikan Kesehatan Gosok Gigi dengan Metode Permainan Simulasi Ular Tangga Terhadap Perubahan Pengetahuan, Sikap, dan Aplikasi Tindakan Gosok Gigi Anak Usia Sekolah di SD Wilayah Paron Ngaw. Fak. Keperawatan Univ. Airlangga, 2(10), pp. 101-111.

18. Srigupta, A., 2004. Panduan Singkat Perawatan Gigi \& Mulut. Jakarta: s.n. 
19. Sriwahyuni, E., Gita, I. B., dan Santosaningsih, D., 2011. Pengaruh ekstrak kayu siwak (Salvadora perisca) terhadap pertumbuhan Streptococcus mutans. JFK UNBRAW, 3(4), pp. 53-65.

20. Tan, H. H., 1993. Penurunan Jumlah Plak Pada Anak TK Marsudsiwi Pengkol Kapling Jepara tahun 2009. J Jur. Kesgi Politeknik 